\title{
Globalization Streams in Futures Studies
}

\author{
Ehsan MEHRABANFAR \\ Amirkabir University of Technology
}

This paper focuses on economic, political \& cultural changes in respect to globalization. It proposes a conceptual model to discuss the effect of mutual relationships among these concepts in the view point of futures studies. Discussing the literature of globalization and its effect on fundamental concepts of human's life, i.e. culture, politics and economy leads to a better understanding of basic features of these concepts. The connections among these concepts in front of a time line with globalization growth can be put together to make a new conceptual model in order to explain their relationships in future. Proposed model shows that the growth of globalization will dismantle economic, political \& cultural differentiation issues, as globalization will reduce their complexity and discrepancy. In other words, future world is not affected significantly by economic, political and cultural infrastructures since the distinctions among these concepts will be reduced by an overall convergence resulted from Globalization positive trend. To understand the best future we should stand on a tiny point to see the reality. This goal is just reached through right vision to understand the best plausible scenarios. This paper aims to propose a model in order to show the basic impact of culture, politics and economics on world which are the basic pillars events of today, but not for tomorrow.

Keywords: Futures Studies (FS), Globalization, Culture, Politics, Economics.

1 Introduction

The word, "globe", was first utilized in England in 1980s. This word comes from the Latin word Globous meaning sphere. Ize is added to Globe to show a fundamental change with the passage of time. "Globalization" is derived from "globalize" to show the emergence of a new network of social and economic systems [1]. Then, this new combination was mentioned by The Economist Journal in an article titled Globalization of Markets in order to emphasize Italy's increased role in automobile manufacturing across the world in 1983. Many significant works were published about globalization in 1990s, including The End of History by Fukuyama [2], The Clash of Civilizations by Huntington [3], End of Nation-State by Jean-Marie Guehenno [4], and Westernization of World by Serge Latouche [5]. These attempts succeeded in spreading the globalization and entering it into the public culture, politics and economics.

The concept of globalization created a new line of life and a new school of taught which came into existence as a result of McLuhan [6] "Global Village" a concept introduced in the book War and Peace in the Global village.
IMF introduced four basic aspects of globalization including trade, investment, migration \& dissemination of knowledge [7]. Fotopoulos introduced six dimensions: economic, political, cultural, social, technological and ideological globalizations. Steger referred to five dimensions, He added ecological to Fotopoulos list but deleted technological and social [8].

This paper argues that Technological, ideological, ecological and social dimensions can be categorized under the other three bigger dimensions, i.e. economic, political and cultural. For example technological globalization like World Wide Web has changed every one's life, as it facilities connections, ended in a change of culture of communication. In other words we can see technological globalization a category of our big three dimensions, as it has changed culture and also economics and politics. In other words, other dimension change our life through these three main streams indirectly, such as cell phones and social media which have changed at last, culture and also economics and of course, politics. This inference can also be applied for other ideological, ecological or social dimensions. 
This three main categories are also used in many other globalization studies like Wiebelhaus-Brahm, E. [9].

In economics, enormous changes in business and trade affairs are occurred, after globalization rise, since globalization works with Smithian and not Marxian theories. Also Keynesian models in economics do not work anymore, for instance multinational corporations could decrease government's power in economics [10]. In other words government's size has shrank to free capacity for nongovernmental organizations to occupy their power.

As far as politics is concerned, International institutions like United Nations control international relations more than any time before. Government's ultimate power is replaced with global democracy; instead administration roles are assigned to them [11]. Governments cannot decide without support of their people, and also credibility in front of world eyes. Their power is not anymore eternal, but watched and discussed continuously. This change is not in one or two but all nations follow.

Culture is the intersection of all dimensions, the traditional life and the old customs have been attenuated. Change is accepted among all nations, and the advantages of this approach have also become visible in many aspects. Definitely, more intimate relationships among different ethnic groups and nations as well as higher shared values has changed culture. Through social networks, cross cultural relationships see an open new way of communication, trading, learning, playing, or even get married [12].

All these trends are created by a concept called globalization. But the most valuable fact to consider is the effect of politics on economics and the effect of culture on economics and the effect of culture on politics and etc. These mutual relations make these three pillars like a chain. This cyclic movement itself facilitates other changes, leading to even more mutual relationships. This chain is mainly enhanced by globalization.
Futures Studies is a scientific method of thinking and deciding about the future; which attempts to find the most promising futures for human beings among a large number of futures. All subjects in science might be considered in futures studies field, as future studies need to discuss any topic. There are some subjects like globalization that are the leading ones as they can show the big plan. They can affect other disciplines too. These trends are the default assumptions for the major scenarios about future. Therefore, the study on the impact of globalization on the futures studies should be regarded highly important.

To find out the effect of globalization on future studies, this paper looks inside of these basic pillars. They are the main points of change, so that any change is always disseminated from them to human life. This paper aims to conceptualize these relationships so that future studies can see the future of their relationship to human life in a better way.

\section{Globalization Origins}

Globalization roots in history of mankind; in fact cross cultural transactions in trade and science are the first reasons of human integration started mainly from European confronts with eastern civilizations such as following Iranian scholars works [13] [14]. This globalization intensified by some milestones such as Christophe Columbus discovery, which then largely connected lands [14]. However in the Eurocentric view modernity is the main reason of globalization rising, but modernity was not the basic reason but its consequences provide method to connect the departed lands together and by spread of knowledge in medicine and literature globalization in culture and economics grossed [15]. In fact Modernity reinforced globalization growth speed. There are many different stages of pre globalization or globalization completed in history, but after information technology development the new era of globalization growth stream line started [16]. However different scholar has got their own interpretations. 
Jemala divides globalization progress from prehistory globalization to current one, into different three periods [17]. The first period is from 1870 to 1913 , in which a global economy emerged, and Britain introduced itself as the pioneer. In this period economic is the leading parameter. In the second period which starts from the First World War politics is also added to the leading parameters. In this period many economic shocks like the Great Depression and USA Wall Street Crash happened. After the Second World War as a political issue, there were still many other shocks waiting for this period, like 1973 Oil Crisis \& Black Monday collapse in 1987. All of these shocks had a major effect on globalization streams. In fact all of these shocks showed the gap of countries fragmentations and the need of a higher look to economics and also politics. The third period starts with this look. Emergence of international organizations, markets, global projects, and any other multinational issue are the sign of this period [18]. The history of globalization mentioned in these three periods show one thing in common, that all these changes were a reason to boost the globalization. Globalization like an intrinsic need is born and grown in the life of mankind mainly in the last century and is growing to its puberty now.

\section{Globalization: Heaven or Hell}

This argue that globalization growth has brought more negative results than positive ones, still exists! Proponents believe that Globalization ends in wars, more misuse of limited resources, severance of family ties, and the collapse of cultural values. Some scholars state that the globalization boosted only the economy of some countries, but economies of the rest were wrecked. They believe that cultures and traditions should be limited to territories of the same countries, otherwise, cultures, nations, and their histories would not exist, and a gap is always required in order to separate nations from each other[19], [20], [21]; [22]). Although the main body of researchers state that Globalization is generally, a beneficial factor for modern life as this integration has been a great major in reducing racism, inequalities, poverty and improving humanity, communication, cross culture studies, scientific projects and etc. The majority of scholars on this side deduce that the modern, e-commerce-based, and IT-based economies came into existence as a result of globalization. Those countries, being involved in, have built healthier economies. Also the new developed culture is based on further attitudes of governments towards democracy and People's welfare and personal freedom are provided at their best for different races and women ([23]; [24]; [25]; [26]).

These ideas about the globalization are a summary of many ideas discussed repeatedly in many papers. These ideas show how many different opinions exist about this concept. One of the reasons of this controversy is in the nature of globalization concept. Many structures of current world are created based on this concept. Globalization is truly one of those deep concepts which agree or disagree with that, solely is enough to classify different groups. However in futures studies always globalization is a promising trend. This hypothesis has been valid for the last decades and has taken a more rapid rate in the last years, as historical events show that intentionally or unintentionally our little globe has accepted globalization in order to satisfy it new needs. This paper considers globalization as a promising trend for the future which societies will tree on it. However the effect of globalization on economics, politics, and culture, as main pillars of human life is still controversial, and kept as the main question of this paper.

\section{Globalization \& Economics}

However globalization does not only effect economics but mainly does [27]. In other words, economics is like the heart of globalization body, which makes other members alive. Economics methods development mainly refers to the diversification of trading forms [28], leading a broad openness in economics, and also free market approach. For instance, an Indian citizen in a remote village can purchase the 
Stocks of a company in Washington, a symptom of globalization spread even in developing countries [22]; [28]).

Marxism tried to decrease the impact of economics on a global scale but in real world Anti Marxism movements had a more important effect on world economics [29]). So, all nations today are facing with a more globalized economy which is a result of integration of various financial markets. The scale and magnitude of economic globalization is incomparable to any other before ([21]; [28]). Introducing new forms of business has changed economies forms to more flexible, small, massive, connected entities working in a closely connected globe ([30]; [31]). Globalization has increased general turnover of involved countries, supposedly all counties are not yet involved in this chain. Intrinsic barriers in business relations between developed and undeveloped countries still remain unsolved. However considerable number of previous lessdeveloped countries mainly has approached to the markets of developed countries, and as a result, transcended their economies. China and India are the two pioneers of using globalization in the benefit of developing economies. Now they are the leaders of many different markets [32].

The importance about the new economy model is not about the numbers such as capital flows or investments. But seeing the economy as an entity which is really connected and vivid as it should be is the real achievement. Interconnectedness with labor rights, liberal democracy policy in mainstream, international corporations, attention to environmental issues, global health care policies and other issues are which make current economic model more valuable than before. In other words, globalization impact on economic is beyond the numbers.

At the age of globalization, economic issues including manufacture, distribution, market, supportive policies, commercial advertisements, and financial and monetary policies are not limited to territories. In other words, the significance of time spans and geographical distances is omitted. The governments cannot make decisions on their domestic economies unless they have considered international conditions. In other words, globalization has spread its dominance all over the world. Globalization has brought the game to an international format. This is why players now are playing faster and with more ambition. In current world, a great number of causes are regarded in relation with development and completion of globalization. The most significant ones are listed below:

1. Communication: as a lot of industries has been speeded up in recent years. The books of a large library are stored in a hard disk. By the help of information technology progress communication has speeded up the communication and has added many new ways to transfer data [10]. Mass Media in different countries have been growing as fast as possible, so that by use of new technologies able to easily transmit news to people all around the world [11]. Social networks as the main pioneers of modern communication, including Facebook, twitter and other social networks has made information transmission fast and easy around the globe. Liberalization and access to data for all has been acknowledged, and sharing information is astoundingly facilitated.

2. Multi-National Corporations: As soon as multi-national corporations were established, dependency on particular governmental economics decreased. Microsoft Company, for example, as one of the largest companies with modern technologies owns 100 billion dollars of equity. Corporations like Coca Cola or Mc Donald have spread their markets to all countries [33].

3. Human Rights: One of the big issues making a considerable impact is human rights demands rise. Martell states that scholars who have a positive approach to globalization refer human right improvement as an advancement made by globalization [33].

4. Environmental Issues: Martell states that in the viewpoint of pluralists, 
environment is an important issue related to globalization [33]. However Scholte states that developments in electronic communications are the basic reason of making environmental issues global [34].

5. IT Technology: All processes of globalization are highly kinked to advancement of technology [35]. A new technology comes and old ones fade away. Modern cell phones are an example; by bringing new culture, economic sectors and political actions. Social movements, after globalization are based mainly on these communication tools [35]. Generally after 1970, globalization concept rises and some decades later many social movements occurs. IT impact on economy is a change of all processes, In the view point of Harvey capitalists could successfully implement these tools to dismantle Fordism by introducing new technologies in manufacturing, information gathering, so that they could enable labels such as "just in time" production.

6. Synergy: A very important parameter usually unseen is the synergy made by all of these parameters. Communication and human rights and information technology together intensify the power of themselves. For example, new tools invented by information technology open new communication tools to develop more human right discussions and enhancing social movements, then politicians try to adopt with new conditions and reform their governments to match with new globalizations rules, which finally increase globalization speed.

\section{Globalization \& Politics}

James Rosenau [36] called the developments occurred in the world the chaos of the policy world. The underlying causes of this chaos, as indicated by him, are: (I) transformation of industrial system into post-industrial and micro-electronics system, (II) new emergence of trans-national issues including air pollution, terrorism and drug trade, (III) the undermining of governments authority and legitimacy as the new issues (IV) the extension of subsystem's functions, (V) creation of decentralizing trends, and (VI) improvement of skills and creation of various orientations in humans.

It was emphasized by [37] that in $20^{\text {th }}$ century a combination of conflict and cooperation has emerged among governments and international organizations, which casted doubt on distinction between domestic policy and international policy. This transformation, moreover, stimulated the process of globalization. Globalization added mobility to money, investment, goods, communications, manufacturing, and business trades. To sum up, globalization decreased the role of governments in favor of corporations and finance sector, so governments could control them less than before [38]. In addition to that they weren't able to manage issues in their own way without considering mass media and public opinions. Since politicians know that they are watched all the time, so started acting in a deliberate practice. Political problems are handled by international institutes, so that many international organizations, like United Nations, have been a venue for all counties to take decisions together. On the other side, public opinions also have affected government's decisions; public have reached to this point that they have got the ability to make decisions against men of power and impose their ideas to governments.

This change stream is started by Adam Smith theories in the contrast of mercantilists, as he founded liberal economy which focuses on the markets rather than politics. He and his fellows in classical economics believe that the best hand to control the markets is the market hand not the political actions [23]. He believed, each intend aims to maximize his own benefit but at last will benefit the society although this was no part of his first intention. However Marx later criticized Smith's free market theory. He argues that considering each one intention is no aid to a society. Marxists believed that capitalism is a negative sum game; as rise of some countries will indirectly lead to fall of some. However Neo 
Marxists generally have maintained a more pessimistic view about capitalism [23]. As capitalism has survived, globalization has grown based on its results. Even some scholars put capitalism in their definition of globalization as Krishna see it as the accelerated spread of capitalist style production over many nations[39].

Smith emphasizes on the free trade ability to improve human creativity and also to reinforce national and international production's engines. In fact he argues that commerce can awaken power in people, and subsequently the power of states will be limited. This approach was called neo liberal globalization. But Marx approach emphasized on the dimension of political, social and power aspects of globalization. He argues that this reasoning is not always true about power consolidation; and also the inequality in achievements distribution is always occurred in the history of capitalism [40].

However in the view point of history, Marxist \& Communism failed in the Eastern Europe and former USSR in the end of $20^{\text {th }}$ century but free market still exists. [41] emphasizes that this failure of Marxists have brought startling relevance of Smith concerns about those types of current protestors, that they follow some new religions-based social and cultural issues rather than economical ones. These protests like Arab springs in the recent years are more based on social issues concerns. So Pack states that the soul of Marx theories which was based on social and cultural dimensions rather than economic issues is still alive however the victory of capitalist structure is not what Marx wanted. Pack tries not to defend Marx but by an impartial judgment he refers to some correct notes in Marx manifestation [41].

\section{Globalization \& Culture}

Beliefs, attitudes, and behaviors of people change slowly. But, when in the second half of $20^{\text {th }}$ century, globalization greatly widespread, they started reforming promptly. This transformation was even observed in communication and eating habits. For instance, Macdonald and Apple stores became available all over the world. Technology advancements mainly in information technology created new social experiences [33]. This modern industrial technologies made world a smaller and faster place called third wave by Toffler in his book, The Third Wave [42]. As he discusses that, this wave has come into existence after completion of industrial wave, the second wave, and agriculture industrialization the first wave. This wave is based on technological advancements but continued by cultural diffusion.

Improvement in broadcasting via mass media and social networks helped small and large countries to communicate their cultures and traditions easily. USA and USSR both tried to promote their culture's attraction globally, however USA could win this war too. USA could successfully stand on the first place of cultural attention, so that only Hollywood mass production is enough to feed the entire world needs [33].

Ritzier studies three viewpoints about the impact of globalization on cultures; listed as cultural differences, cultural hybridization, and cultural convergence. In the first one, the barriers of global trends are put into emphasis [43]. Furthermore, the world should be regarded as a mosaic of different cultures. In other words, an emphasis is put on culture's attempts to be protected against globalization. In the second view, cultures are hybridized as a result of globalization and are new unique cultural links. This hybridization does not belong to any domestic culture or the world culture. The world processes, instead, are combined with local realities in order to form a distinct hybridization. As a result, the world heterogeneity is allowed to continue. In the third, globalization continues the trend of revealing points of similarity across the world. According to radical view point, expressed by proponents of this group, the global cultural changes and the undermined boundaries of cultures are the consequences of globalization.

Some theorists, view globalization as a process in which the world is post-modernized [44]. This viewpoint is resulted from 
transformation of modernism to post modernism by globalization spread. This approach makes culture penetration into all spheres of life [45]. Time spans and geographical distances are not matter of consideration any more [49]. This change is more revealed in culture and trade. Any person can purchase favorable products from the stores all over the world, regardless of geographical distances. So culture of marketing is also globalized as different courtiers need different considerations. People around the world still keep cultural distinctions however their similarities increase [46].

Martell [33] states that culture has shaped globalization enormously and globalization in response to this action should counteract with mutual relation of globalization's culture and local cultures. Cinema and TV played a great role in the diffusion of cultural globalization. As Martel [33] states that in some developed countries the ownership of TVs in 1950s is increased from 10 percent to 90 percent at the end of this decade. This start point then is completed by the emergence of satellites and cable TVs. For instance He refers to World Cups as a phenomenon that today is covered all over the world. Culture is not a local phenomenon any more, but a global concept.

\section{Globalization \& Futures Studies (FS)}

Many different concepts are influenced by globalization, in this regards futures studies relation with globalization is a multilateral investigation. Since globalization is penetrated to all aspects of life; futures studies needs a comprehensive and holistic look to work [47], this connection is a main concern for all scenarios planned about future. No futurist is able to propose any scenario without considering this trend.

The features of past and present issues are available to see while those of future are difficult to be pointed. However, the characterization of old past is as much difficult as future, because its details cannot be found in the periods of transition. Futures Studies should connect past to present and present to future. It requires using practical methods and robust techniques in order to study the future at its best. It aims to propose different scenarios for future.

The globalization in respect to future studies can be viewed in different definitions, as FS is largely related to any field. Scholte [48] defines the phenomenon of globalization as a process in which "supraterritoriality" is created so that borders no long matter. This word brings with itself liberalization and homogenization. As asserted by Held [49], it is the globalizing of social life of people and the social interactions among them that shape the majority of globalization. And, Giddens [50] regards it the globalizing of social relationships. Based on which aspect to consider, globalization can be defined in many different ways, because it is really related to many issues. Globalization make economic, political, and cultural substructures be integrated playing a key role in future.

\section{Conceptual Model of FS-Globalization}

As discussed in previous parts, globalization makes our world smaller, faster and more flexible. This changes the steady state condition of life. Globalization is a fundamental concept because it effects on all other important concepts such as the three pillars of our current world discussed in this paper. To have the right perspective this study goes through the literature of these concepts and their connection with globalization. A model which shows their connections in the present time and also in future is shown in Figure 1. However the default hypothesis of this model is the constancy of current trend as the most probable. Based on this hypothesis globalization is a positive trend in the future and will continue to its growth. Our contemporary life mainly depends on economics and politics and culture. To show the strong connection of our current world to these three parameters thick lines are shown for the connection of future and culture and economics and politics. But when time passes and globalization boosts this connection is faded. So in the second step this connection is shown with dotted lines. In the third part of 
this model in the distant future, even this connection is more faded. In other words, globalization is a steady line which will improve. Future dependency to economics will be reduced; as its influence on future events decreases. As discussed in previous parts there are many economic theories, like
Smithian or Marxian, But in the long run all of these theories are applied and tested, so surely a time in a distant future will be less dependent on economic theories because theoretical economics fluctuations among different theories is reduced.

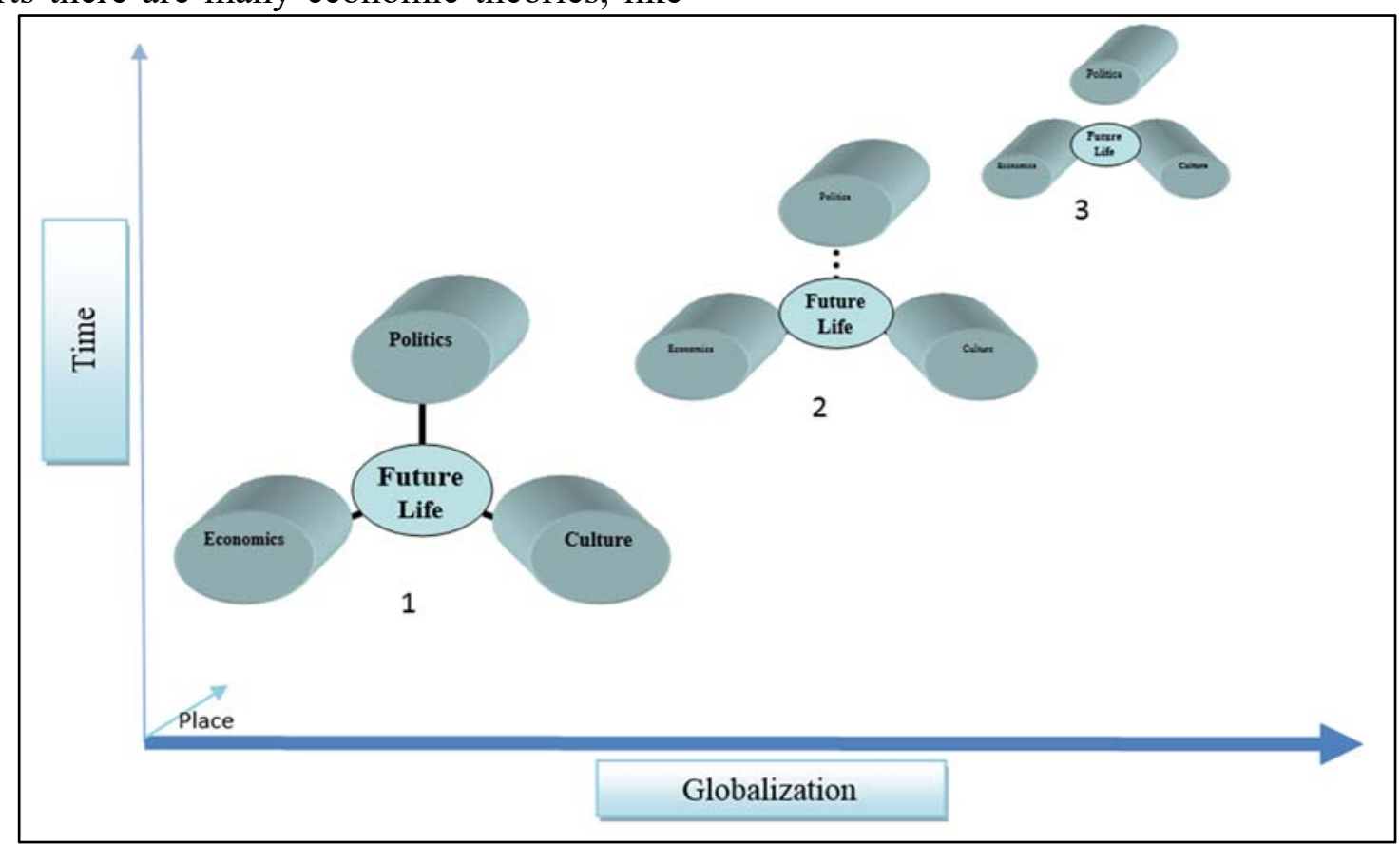

Fig. 1.Globalization Streams

Future events will be less dependent on culture distinctions as cultural merging will be increased as a convergence improved by globalization progress. When all people around the world could possibly share their knowledge, information and their ideas then cultural convergence is boosted. This model simply is referring to this fact that globalization affects our whole life so that in future, human life dependency will turn to other factors.

History shows that by globalization improvement even in its early age odd issues rather than usual ones were on the main concerns of FS scholars. In comparison to $20^{\text {th }}$ century it is obvious that political differences in different nations are reduced in the view point of theories and discourses; also cultural distinctions be the help of new forms of communication is faded; and the scale of economic theories distinctions has decreased.

\section{Conclusions}

The Enlightenment era and emergence of modern schools of cultural, economic and political thoughts broke the old fashioned ideas in human history. After this milestone, Knowledge spread in all stages of human life. This transformation in human life continued to build a new system in the most important pillars of life, i.e. economics, politics and culture. As a result, change became ordinary and future visions came to be ambiguous; so soon future thinking or planning became a requisite for strategists, politicians, managers and etc. This change which brought a lot of changes with itself was named globalization. Robertson [51] considers globalization the compression of the world and awareness. Wiebelhaus-Brahm [9] also refers to growing interconnectedness as the main feature of globalization. In other words, economic, cultural, and political relations are more intervolved. Globalization brings changes both with advantages and disadvantages. As a 
result, different viewpoints are mentioned by proponents and opponents in this issue. However, most scholars agree that globalization shape new phases of life and a climate of change in the substructures of human life i.e. economy, culture and politics. In this regard, Robinson [27] states that globalization is the first step to know $21^{\text {th }}$ century. This trend is reinforced by development of information technology and mass media developments. People share many more values, data, information and even memories with each other. Now, economical models resemble more to each other. The world organizations make the world of politics more unified. These shared concepts about global village roots from long periods of transition in which large number of attitudes are adopted all over the world.

Globalization as a promising trend is one of the fundamental assumptions of Futures studies. This trend requires a more detailed consideration as globalization is one of the basic parameters having impact on future events. Therefore, all futurists have discussed it in details. The concept of Third Wave introduced by Toffler is an instance of such attempt, in which features of postindustrial world is characterized in detailed dimensions like economics, politics and culture. There are surely more items to add to these three dimensions discussed in this paper but in a more large scale look other ones might be categorized under these dimensions.

The past and present events are put under three structures i.e. economy, culture and politics. Any change of these sensitive concepts is a change for all other ones. This is why this paper looks at them like a chain, as they have seen considerable changes in time together. For example culture of different nations differed from their past. Change in politics and economics changed culture as more international relationships and social deals is one reason. There is a convergence for all of them to a point designed by globalization. Such changes increased with information technology in second half of $20^{\text {th }}[1]$ century. Indeed, a more compressed world is developed, in which the massive coverage of media, the great storage of data, and the increased flow of information makes it easy to transfer the most trivial incidents across the world to all people in a few seconds [33]. This change is a sign of globalization which affects politics, economics, culture, and at last each person's life; as slow trend of changes in $17^{\text {th }}$ century is substituted with rapidness in 21th century. As indicated in Toffler's book The Third Wave, humans' life has been improved from industrial to post-industrial period. Contemporary globalization is boosted by many other factors like technology advancements, new trade methods and communication styles, modern military equipment's, diversifying music styles, food production advancement, international corporations, internet use around the world, new travelling methods, mass media growth and etc. However all of these subjects can be categorized under one of the big three.

The present study concludes that globalization brings assimilation of cultures resulting in the reduction of cultural impact on related future events. A similar analogy is seen in economics and politics concepts. Convergence to use a unique economic and political model all over the national states resolves many financial and political disagreements. However now after years of arguments there is no disagreement of different theories but at least many of them are canceled off from the list. In fact this paper does not state that humans should reach to a unique point but to dismantle useless theories and discrepancies among different nations. Surely any future in which all the world is governed by one culture or political power and economical model is a backward movement. But this paper asserts that future events thanks to globalization will be disconnected from its current wings and will move its affinity to new areas of attention like ecological or health issues. However there still will be differences among people as anyone is born with distinctions.

\section{References}

Globalization (1959). Online Etymology Dictionary, Available: 
http://www.etymonline.com/index.php?term [15] L. Sklair, "Competing conception of $=$ globalization. globalization", Journal of World System

[2] F., Fukuyama, "the end of history", National Research, Vol. 2, pp 143-163, 1999. Interest, Vol. 16, pp. 3-18, 1989.

[16] R.P. Clark, the global imperative: an

[3] S. P. Huntington, "The clash of civilizations", interpretive history of the spread of Foreign affairs, Vol.72, No.3, pp 22-49, 1993. humankind, Boulder, CO: West view Press,

[4] J. M. Guéhenno, the end of the nation-state, 1997. Minnesota: Minnesota Press, 1995.

[5] S. Latouche, The Westernization of the world: The significance, scope and limit of the drive

[17] M., Jemala, "Evolution of foresight in the global historical context", Foresight, 12(4), 65-81, 2010.

towards global uniformity, London[18] J. R. Short, A. Boniche, Y. Kim, \& P. L. Li, Cambridge, 1996.

"Cultural globalization, global English, and

[6] M, .McLuhan, Q. Fiore, \& J. Agel, War and geography journals", The Professional peace in the global village, Vol. 127, NY: Geographer, Vol. 53, No. 1, pp 1-11. 2001.

Bantam books, 1968.

[19] W. F. Waters, "Globalization,

[7] I. M. F. Staff (2000). Globalization: Threat socioeconomic restructuring, and community or Opportunity?. Available: https://www.imf.org/external/np/exr/ib/2000/ 041200to.htm

health", Journal of Community Health, Vol. 26, No. 2, pp 79-92, 2001.

[20] K. N. Waltz, "Globalization and

[8] Takis, Fotopoulos, "Globalization, the governance", Political Science \& Politics, reformist Left and the Anti-Globalization Vol. 32, No.4, pp 693-700, 1999

'Movement, Democracy \& Nature", Th£21] W. Greider, One World, and Ready or Not: International Journal of Inclusive The Manic Logic of Global Capitalism, New Democracy, Vol. 7, No. 2, 2001.

York: Simon and Schuster, 1997.

[9] E. Wiebelhaus-Brahm (2002). Globalization[22] M. Castells, End of Millennium, Oxford: Modernity, and Their Discontents, Available: Blackwell, 1998.

http://papers.ssrn.com/sol3/papers.cfm?abstr[23] A. Hoogvelt, Globalization and the act id $=1666871$.

[10] M. Waters, Globalization, Key Ideas, Economy of Development, London: Palgrave London: Routledge, 1995. Macmillan, 1997.

[11] D. Archibugi, M. Koenig-Archibugi, and R[24] R. Gilpin, the Challenge of Global Marchetti, Global democracy: normative and Capitalism: The World Economy in the empirical perspectives, London: Cambridge 21stCentury, Princeton: Princeton University University Press, 2012.

Press, 2002.

[12] Arjun, Appadurai (1990). Disjuncture and25] J. Stiglitz, Globalization and Its Discontents, difference in the global cultural economy, NY: W.W. Norton \& Company, 2002

Cultural Theory: An Anthology, Available[26] Z., Bauman, Globalization: the Human http://www.arjunappadurai.org/articles/Appa Consequences, NY: Columbia University durai_Disjuncture_and_Difference_in_the_G Press, 1998.

lobal_Cultural_Economy.pdf

[27] W. I. Robinson. Promoting polyarchy:

[13] M. R. Neyestani, \& P. McInturff, "Cultural and Religious Identities in an Era of Information and Communications globalization, US intervention, and hegemony Vol. 48, London: Cambridge University Globalization", Communications of the IIMA[28] P. Dicken, Global Shift 3rd edition, New Vol.6, No.4, p8, 2015.

[14] H. Chehabi, Iran in the Middle East: Transnational Encounters and Social History, Vol. 56, NY: IB Tauris, 2015. York: The Guilford Press, 1998.

[28] J. A. Ocampo (2015). Capital account liberalization and management, Available:http://www.wider.unu.ed u/publications/workingpapers/2015/ 
en $\mathrm{GB} / \mathrm{wp} 2015$

048/_files/93928817240276914/def ault/wp2015-048.pdf

[29] L. Martell, "Globalization and Economic

Determinism”, Global Studies Association[40] J. Baylis, S. Smith, \& P. Owens, (Eds.). The conference: Challenging Globalization, globalization of world politics: An Royal Holloway,London, UK, 2009.

[30] S. Gill, "Globalization, Market Civilization and Disciplinary Neoliberalism, Millennium"[41] S. J. Pack, Aristotle, Adam Smith and Karl Journal of International Studies, Vol. 24, No. 3. 1995.

[31] M. Geyer, \& C. Bright, "World History in a Elgar Publishing, 2010.

Global Age", American Historical Review[42] Alvin, Toffler, the Third Wave, London: Vol. 100, No. 4. 1995.

Bathnam Books, 1980.

[32] S. Rao, \& V. Mudgal, "Introduction[43] G., Ritzier, globalization: the essentials, Democracy, civil society and journalism in Madlen, Chichester: Wiley-Blackwell, 2011. India" Journalism Studies, (ahead-of-print)[44] A.P. Smith, Towards a Global culture, In M Vol.16, No.5, pp 1-9, 2015. [33] L., Martell, the sociology of globalization, Nationalism, Globalization and Modernity,
London: Polity Press, 2010.

[34] J. A. Scholte, Globalization: A critica[45] R. Williams, Culture, Fontana, Glasgow, introduction, London: Palgrave Macmillan, 1981. 2005.

[46] P. Hopper, Understanding cultural

[35] K. Nash, Contemporary Political Sociology: globalization, London: Polity Press, 2007. globalization, politics and power, Chichester[47] W. Bell, Memories of the Future, New John Wiley \& Sons, 2009.

Brunswick: Transaction Publishers, 2011.

[36] J., Rosenau, Distant Proximities: Dynamic \$48] J. A. Scholte, "Global civil society", the Beyond Globalization, Princeton: New York, political economy of globalization, Vol. 173, 2003. pp 192-93, 2000.

[37] Roger, Haywood, Manage your reputation[49] D., Held, \& A. Mc Grew, Global London: Kogan, 2002.

[38] L., Christopher, “deep Federalism: Culture, CA: Stanford University Press, 1999. Respecting Community Difference in[50] A. Giddens, Modernity and Self-Identity: National Policy", Canadian Journal of Self and Society in the Late Modern Age, Political Science, Vol. 39, No.3, pp 481-506, Stanford: Stanford University Press, 1991. 2006.

[51] R. Robertson, Globalization:SocialTheory \& Global Culture, Sage, London. 1992.

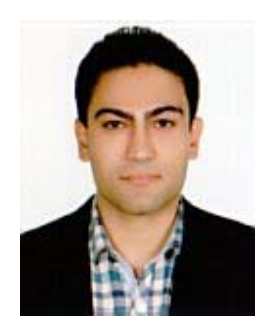

Ehsan Mehrabanfar received MSc in Master of Business Administration from Amirkabir University of Technology (Iran) in 2012; He has been involved in many research works in various scopes such as strategic management, future studies, social science and human resource management. He has published over 30 different publications in Persian and English language. He is the founder \& editorial manager of International Journal of Modern Management \& Foresight (IJMMF.com) published in Australia. 